\title{
Nytt sprengstoff i moraldebatten
}

\begin{abstract}
VG har som landets første avis digitalisert sitt historiske arkiv. Mer enn 800000 avissider fra starten i 1945 er tilgjengelig i arkivet. Første treff på Tidsskriftet er fra 1946. Under tittelen «Nytt sprengstoff i moraldebatten» sto det i avisen 27.12. 1946 at «Lægeforeningens tidsskrift reagerer skarpt mot et opprop utsendt av kristelige leger». I Tidsskriftet ble saken kommentert av Hans Jacob Ustvedt (1903-82), som samme år var ansatt som overlege ved Ullevål sykehus (Tidsskr Nor Lægeforen 1946; 66: 787), og i en lederkommentar i samme nummer (s. 793). Nedenfor følger et utdrag av Ustvedts innlegg.
\end{abstract}

\section{Lægene og seksualmoralen}

En del norske læger er i den siste tid blitt tilstillet et dokument som det er grunn til å stanse opp ved. Det dreier seg om en oppfordring til å undertegne et «opprop til det norske folk». Oppropet uttaler seg om seksualmoralen, og skal oversendes Storting og Regjering. Det er allerede undertegnet av et mindre antall kolleger.

Det opplyses ikke i dokumentet om hvem som er initiativtakere i saken. I forbindelse med den utglidning i seksualspørmålet som påståes å herske i de tidlige ungdomsår «ventes det en uttalelse fra lægehold om den medisinske side av saken». Det standpunkt som norske læger oppfordres til å protestere mot er formulert slik: «Fri tilfredsstillelse av seksualdriften i ungdomsårene fremholdes som nødvendig for å frigjøre sinnet og oppnå størst mulig sjelelig sunnhet og menneskelig lykke.»

Overfor en så outrert formulering kan vel noen hver i første omgang føle seg beføyet til å protestere og undertegne uten å tenke saken nøyere igjennom. Men saken langt mer komplisert enn som så. [...]

En spør seg uvilkårlig: Hvem er det som «venter en uttalelse fra lægehold»? Hva skal en slik uttalelse brukes til? Hvem er det man samler underskrifter mot? Hvem har uten reservasjon hevdet at fri tilfredsstillelse av seksualdriften i ungdomsårene er nødvendig for å frigjøre sinnet osv.? Hvilken medisinsk autoritet har i våre dager gått inn for seksuelt anarki slik som dette antyder? [...]

Endelig spør man seg: Hvorfor har bare et utvalg av norske læger fått henvendelsen? Hvem har foretatt dette utvalget, og på hvilket grunnlag? Det ligger nær å spørre om man virkelig ønsker en ansvarlig medisinsk uttalelse, eller om målet snarere er en samling vitnesbyrd. 